\title{
Dietary ambon lumut banana stem extract Musa cavendishii var. dwarf Paxton as an immunostimulant for white spot disease prevention in Pacific white shrimp Litopenaeus vannamei
}

\section{Penggunaan ekstrak batang pisang ambon lumut Musa cavendishii var. dwarf Paxton sebagai imunostimulan untuk pencegahan penyakit white spot pada udang vaname Litopenaeus vannamei}

\author{
Afriani Ramadhan ${ }^{1}$, Sri Nuryati ${ }^{2 *}$, Nur Bambang Priyoutomo ${ }^{2}$, Alimuddin Alimuddin ${ }^{2}$ \\ ${ }^{1}$ Study Program of Aquaculture, Faculty of Animal Husbandry and Fisheries, Tadulako University \\ Campus Universitas Tadulako, Palu, Central Sulawesi, Indonesia 94118 \\ ${ }^{2}$ Department of Aquaculture, Faculty of Fisheries and Marine Science, Bogor Agricultural University \\ Campus IPB Dramaga Bogor, West Java, Indonesia 16680 \\ *E-mail: sri.nuryati606@gmail.com
}

\begin{abstract}
This study was aimed to evaluate the dietary ambon lumut banana Musa cavendishii var. dwarf Paxton stem extract on the immune responses, growth, and survival rate of Pacific white shrimp against white spot disease. Ambon banana steam extract was obtained by maceration method using ethanol. The shrimps fed by pellet containing ambon banana stem extracts with different dosages for 29 days, i.e designated as 0.1 (A); 0.3 (B), and 0.5 (C) g/ $\mathrm{kg}$, the diet treatment without ambon banana stem extract without challenged test (K-), and diet treatment without ambon banana stem extract with challenged test $(\mathrm{K}+)$. Each treatment consisted of three replications. Feeding was conducted for 29 days of maintenance (four times a day). The results showed that the immune responses (average total hemocyte count: $45.15 \times 10^{6}$ cells $/ \mathrm{mL}$, phenoloxidase activity $1.03 \pm 0.08 \mathrm{OD}$, respiratory burst $0.95 \pm 0.04$ OD, phagocytic activity $94.33 \pm 1.53 \%$, growth (specific growth rate: $7.79 \pm 0.06 \% /$ day, feed ratio conversion was $52 \pm 0.01$ ), and survival of treatment $\mathrm{C}$ (survival rate 100\%) were higher compared with the treatment $\mathrm{K}+$ (total hemocyte count: $3.83 \times 10^{6}$ cells $/ \mathrm{mL}$, phenoloxidase activity $0.04 \pm 0.01 \mathrm{OD}$, respiratory burst $0.18 \pm 0.06 \mathrm{OD}$, phagocytic activity $5.67 \pm 0.58 \%$, specific growth rate: $2.61 \pm 0.08 \% /$ day, feed conversion ratio $2.11 \pm 0.02$, survival rate: $50 \%$ ). Therefore, banana stem extract at a dose of $0.5 \mathrm{~g} / \mathrm{kg}$ everyday diet can be used to improve growth and nonspecific immune system against white spot disease on Pacific white shrimp.
\end{abstract}

Keywords: Pacific white shrimp, white spot disease, immune response, Ambon banana stem extract

\begin{abstract}
ABSTRAK
Penelitian ini bertujuan untuk menguji dosis optimal ekstrak batang pisang ambon melalui pakan dalam meningkatkan respon imun, pertumbuhan dan kelangsungan hidup udang putih terhadap penyakit white spot. Ekstrak batang pisang ambon lumut Musa cavendishii var. dwarf Paxton menggunakan metode maserasi dengan menggunakan pelarut etanol. Pakan udang yang mengandung ekstrak batang pisang ambon pada dosis yang berbeda selama 29 hari 0,1 (A); 0,3 (B), dan 0,5 (C) g/kg, pakan tanpa pemberian ekstrak batang pisang ambon dan tidak diuji tantang (K-), pakan tanpa pemberian ekstrak batang pisang ambon dan diuji tantang (K+). Masing-masing perlakuan terdiri atas tiga ulangan. Frekuensi pemberian pakan empat kali sehari selama 29 hari pemeliharaan. Hasil penelitian menunjukkan bahwa perlakuan C respons imun (rata-rata jumlah total hemosit: $45,15 \times 10^{6} \mathrm{sel} /$

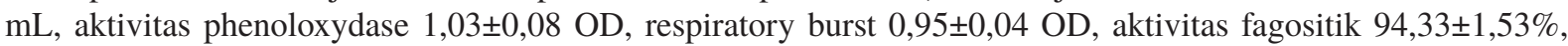
pertumbuhan (laju pertumbuhan spesifik: 7,79 $\pm 0,06 \%$ /hari, rasio konversi pakan $0,52 \pm 0,01$ ), dan kelangsungan hidup (survival rate $100 \%$ ) lebih tinggi dibandingkan dengan perlakuan $\mathrm{K}+$ (jumlah total hemosit: $3.83 \times 10^{6} \mathrm{sel} /$

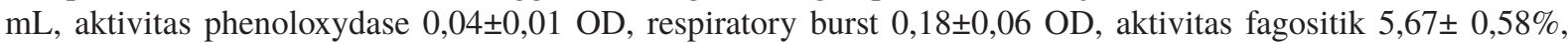

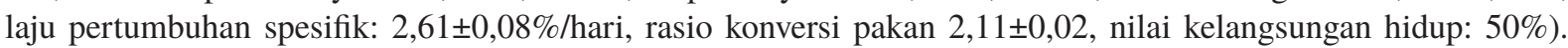
Jadi, ekstrak batang pisang pada dosis $0,5 \mathrm{~g} / \mathrm{kg}$ setiap hari pada pakan dapat digunakan untuk meningkatkan pertumbuhan dan sistem kekebalan tubuh nonspesifik terhadap penyakit bintik putih pada udang putih.
\end{abstract}

Kata kunci: udang putih, white spot, respons imun, ekstrak batang pisang ambon 


\section{INTRODUCTION}

Pacific white shrimp Litopenaeus vannamei is an aquaculture export commodity that has made great contributions to the Indonesian economy. However, a factor that often becomes a cause of harvest failures is an infection caused by viruses. Indeed, a problem viral disease is the white spot, which can engender mortality up $100 \%$ (Huang et al., 2011). Pacific white shrimp has a nonspecific immune system in protecting the body against viral, bacterial, and pathogenic attacks. The immune system of the shrimp need to be increased i.e. by mean of immunostimulant (Ridlo \& Pramesti, 2009), vitamins (Darvishpour et al., 2012), and probiotics (Lakshmi et al., 2013).

Immunostimulant is a material that can increase the function of immune system components (Baratawidjaja \& Rengganis, 2010). It is usually done with the supplementation of microbial components such as $\beta$-glucan and lipopolysaccharides or dead bacterial cells (Smith et al., 2003). Research using immunostimulant are effective in increasing immune-competence and resistance of shrimp against diseases (Pholdaeng \& Pongsamart, 2010). However, immunostimulants are both not easily available and quite expensive, leading to a need to develop alternative immunostimulant that can function as an immunostimulant in shrimp body. A few natural materials have a traditional medicine function to improve environmental conditions, relatively cheap, abundant, making them alternatives in substituting various types of medicines that can cause a pathogen to become resistant. Ingredients that function as growth promotor, the immune system that acts as antibacterial and antivirus for host immune system (Hai, 2015). A natural ingredient that can be used is the banana stem.

Banana stem is a potential agricultural waste that has not yet been fully utilized. According to the data of the Central Bureau of Statistics (2015), the production of banana reached $6,862,567$ tons in 2014, which increased to 7,299,266 tons in 2015. The Central Bureau of Statistics and the Directorate General of Horticulture showed that the increasing production of banana would lead to a production of tremendous banana stem waste. Among the different parts of the mentioned banana plant, the stem contains higher immunostimulant active compounds compared to other parts (Loganayaki et al., 2010). Phytochemical analysis results from the center for spices and drugs research (2015) revealed that ambon banana stem moss extract contained tannins, saponins, and flavonoids, which have antibacterial, antivirus, and immunostimulant potential (Citarasu, 2010).

Research on the use of ambon banana stem extract as the immunostimulant to control white spot disease in Pacific white shrimp farming in floating net cage at a dose of $0.5 \% \mathrm{~g} / \mathrm{kg}$ preand post-challenge test had a survival rate of $100 \%$, while that of the positive control was $0 \%$ (Simanjuntak, 2016). The mentioned research has already determined the best daily frequency dose of $0.5 \% \mathrm{~g} / \mathrm{kg}$ feed but failed to determine if the $0.5 \%$ dose can still be decreased to an optimal dose of ambon banana stem extract for shrimp feed. Thus, the aim of the present study was to evaluate the optimal dose of ambon banana stem extract through feed in increasing immune response, growth, and resistance of Pacific white shrimp against white spot disease.

\section{MATERIALS AND METHODS}

\section{Banana stem extract preparation with maceration method}

The banana stem used in the previous study was brought from Pabuaran, Cibanteng, District of Bogor, Indonesia. The part of the stem that was \pm 5 months old was cut into smaller pieces and the extraction was performed using ethanol solution (96\%). The simplices of the stem were extracted at a ratio, between samples and solution, of 1:10. Extraction was performed using maceration method for 24 hours (Thermoshaker) with a speed of $160 \mathrm{rpm}$ at $40{ }^{\circ} \mathrm{C}$. The filtrate was strained, gathered, and evaporated with a rotary evaporator at $40{ }^{\circ} \mathrm{C}$. The obtained solution was a thick extract of ambon banana stem. Active components was quantitatively (Phyto-pharmaceutic) analyzed at the center for spices and drugs research following the thin layer chromatography (TLC) method. The results showed that ambon banana stem contains flavonoids (19.52\%), saponins (8.38\%), and tannins $(4.94 \%)$

\section{Feed preparation}

A completely randomized design with 6 treatments (each replicated 3 times) was used in this study. Ambon banana stem extract was mixed with a given feed according to treatments as follows: 0.1 (A), $0.3(\mathrm{~B})$, and $0.5 \mathrm{~g} / \mathrm{kg}$ feed (C). The extract was diluted in $300 \mathrm{~mL}$ distilled water solution that was previously mixed with white egg (as a binder) at a concentration of $2 \%$. The solution was then evenly mixed with a 
commercial shrimp feed with a protein content of $30 \%$. Afterward, the feed was dried for \pm 1 hour and was finally ready to be used or stored in closed plastic bags in a refrigerated room for further usage.

\section{Aquarium preparation}

Aquariums $\left(65 \times 30 \times 35 \mathrm{~cm}^{3}\right)$, that were previously cleaned and disinfected using chlorine solution at $30 \mathrm{mg} / \mathrm{L}$, and dried for 24 hours, were used in the present study. After the drying process, the aquariums were filled with water and the aeration system installed to continuously supply oxygen. A total of 20 aeration points was used according to the number of needed aquariums (15 aquariums for survival rate observation and 5 aquariums for hematology tests).

\section{Shrimp rearing}

The test animal used in the present study was Pacific white shrimp, at an average body weight of $4.18 \pm 0.02 \mathrm{~g}$, that was brought from floating net cage shrimp farming site, on thousand islands. The test shrimp was confirmed specific pathogen free against WSSV disease through PCR. Prior to treatments, the test shrimp were acclimatized for 14 days in experimental aquariums at a stocking density of 10 shrimp/aquarium and fed four times daily with a commercial feed (at-satiation). Water quality in the medium was maintained by mean of siphoning $10 \%$ of the water volume daily. The shrimp were not fed 24 hours prior to starting the experiment in order to dispose of feed residues in the shrimp digestive tract. The rearing of test shrimp was performed during 29 days.

\section{Virus preparation and WSSV infection}

The preparation process of virus inoculant was carried out following Nunan and Lightner (2011) method. First, one gram of shrimp infected by WSSV was ground with a mortar into fine particles. Afterward, the ground shrimp was suspended in a $9 \mathrm{~mL}$ sterile seawater, and then centrifuged at $3000 \mathrm{rpm}$ for 20 minutes at $4{ }^{\circ} \mathrm{C}$. The supernatant was then centrifuged at $8000 \mathrm{rpm}$ for 30 minutes at $4{ }^{\circ} \mathrm{C}$. The obtained supernatant was finally filtered using a Millipore with a pore size of 0.45 $\mu \mathrm{m}$, leading to the obtention a virus suspension at a concentration of $10 \%(\mathrm{w} / \mathrm{v})$. Transmission test was performed through intramuscular injection with $0.1 \mathrm{~mL}$ of virus solution, that was diluted with phosphate buffered saline (PBS), on the $3^{\text {rd }}$ abdominal segment. The negative control shrimp were injected with PBS (Yao et al., 2015).

\section{Tested parameters}

Growth performance parameters consisted of survival rate that was daily observed until the end of the treatment. The mentioned parameter covered the calculation of survival rate, that was performed at the end of the treatment, specific growth rate, and feed conversion ratio.

Hematology test consisted of parameters such as total hemocyte count (THC), phenoloxidase activity (PA), respiratory burst (RB), phagocytic activity (PHA), and WSSV presence confirmation with PCR. Hematology test samples were collected on day 1 (before treatment), day 21 (before challenge test), day 23 (day 1 post challenge test), day 25 (day 3 post challenge test), day 27 (day 5 post challenge test), and day 29 (day 7 post challenge test).

Water quality measurement of the rearing medium was composed of temperature $\left({ }^{\circ} \mathrm{C}\right), \mathrm{pH}$, dissolved oxygen $(\mathrm{mg} / \mathrm{L})$, and total ammonia nitrogen $(\mathrm{mg} / \mathrm{L})$. Water sample collections for the water quality parameters were carried out at both the beginning and end of the research.

\section{Total hemocyte}

The determination of total hemocyte count (THC) was done by collecting $0.1 \mathrm{~mL}$ of hemolymph, to which a $0.7 \mathrm{~mL}$ of anticoagulant was added (EDTA 10\%), homogenized for 5 minutes in a microtube and finally counted with a hemocytometer on a microscope using a magnification coefficient of 400. THC was calculated using the following formula:

$$
\begin{aligned}
& \text { THC }(\text { cell } / \mathrm{mL})= \\
& \frac{\text { counted cell } \times \text { dilution factor }}{\text { box volume }} \times 1000
\end{aligned}
$$

\section{Phenoloxidase activity}

Phenoloxidase activity (PA) of shrimp hemocyte was measured based on the formation of dopachrome, resulting from L-DOPA (L-dihydroxyphenylalanine), by mean of Hsieh et al. (2008) method. Body fluids (1 mL) was centrifuged at a speed of $3500 \mathrm{rpm}$ at $4{ }^{\circ} \mathrm{C}$ for 10 minutes, the supernatant disposed and the pellet re-diluted with cacodylate-citrate buffer $(0.01 \mathrm{M}$ sodium cacodylate; $0.45 \mathrm{M}$ sodium chloride; 0.01 $\mathrm{M}$ trisodium citrate; at a $\mathrm{pH}$ of 7.0 ), re-centrifuged at a speed of $3500 \mathrm{rpm}$ at $4{ }^{\circ} \mathrm{C}$ for 10 minutes. Afterward, the supernatant was disposed, the pellet diluted in $0.2 \mathrm{~mL}$ cacodylate buffer, and $0.1 \mathrm{~mL}$ was placed in a microtube, incubated with $0.05 \mathrm{~mL}$ trypsin (T-0303, Sigma, $1 \mathrm{mg}$ / 
$\mathrm{mL}$ ) that functioned as activator for 10 minutes at temperature of $25-26{ }^{\circ} \mathrm{C}$. After the incubation, $0.05 \mathrm{~mL}$ of L-DOPA ( $3 \mathrm{mg} / \mathrm{mL}$ cacodylate buffer) was added to the solution and left to rest for 10 minutes, and $0.8 \mathrm{~mL}$ cacodylate buffer was finally added. The obtained solution was inserted in a microplate reader and the optical density (OD) was measured at a wavelength of $490 \mathrm{~nm}$.

\section{Respiratory burst (RB)}

The respiratory burst of shrimp hemocyte was counted based on NBT reduction as a superoxide anion $\left(\mathrm{O} 2^{-}\right)$measurement. Following Immanuel et al. (2012) method, $50 \mu \mathrm{L}$ of hemolymph and anticoagulant solution was incubated for 30 minutes at room temperature. Next, the solution was centrifuged at $3000 \mathrm{rpm}$ for 20 minutes and the supernatant disposed of. Then, $100 \mu \mathrm{L}$ NBT in HBSS (Hank's buffered salt solution) solution at a concentration of $0.3 \%$ was added to the solution and left to rest for 2 hours at room temperature. Next, the solution was centrifuged at $3000 \mathrm{rpm}$ for 10 minutes and the supernatant disposed of. The formed pellet was rinsed 2 times with methanol (70\%). Afterward, $120 \mu \mathrm{L}$ of $\mathrm{KOH}(2 \mathrm{M})$ and 140 $\mu \mathrm{L}$ of DMSO (dimethylsulfoxide) were added to dilute the pellet and the diluted pellet was placed into microplate to measure the optical density (DO) using a microplate reader with a wavelength of $630 \mathrm{~nm}$. The RB was avowed as a reduction of NBT per $10 \mu \mathrm{L}$ hemolymph.

\section{Phagocytic activity}

Hemolymph, $0.1 \mathrm{~mL}$, was placed into a microplate, evenly mixed with $25 \mu \mathrm{L}$ Staphylococcus aureus bacteria and incubated for 20 minutes. Hemolymph, $5 \mu \mathrm{L}$, was then dropped on a glass object to make prep pads that were dried. The fixation was performed with absolute methanol for 5 minutes and stained with Giemsa for 15 minutes. Phagocytic activity was measured based on the percentage of phagocytic cells that perform phagocytosis and was determined using the following formula:

Phagocytic activity $(\%)=$

$\sum$ Phagocytizing cell / $\sum$ Phagocytic cell $\times 100$

\section{WSSV presence confirmation using PCR}

The virus was examined with PCR (polymerase chain reaction) method (KAPA Taq PCR, Boston, USA) that was carried out to confirm the presence of WSSV virus in Pacific white shrimp. The confirmation test that was used in the treatments and post infection was a technique through (5'-GTA-ACT-GCC-CCT-TCC-ATC-TCC-A-3') and 146R2 (5'-TAC-GGC-AGCTGC-TGC-ACCTTG-T-3') primers following the procedure used by Nunan and Lightner (2011).

\section{Feed conversion ratio}

Feed conversion ratio (FCR) of Pacific white shrimp throughout the research was determined using the following formula:

$$
\mathrm{FCR}=\mathrm{F} /[(\mathrm{Wt}+\mathrm{D})-\mathrm{Wo}] \times 100
$$

Note:

$\mathrm{Wt}=$ the average weight of the fish at the end of the study (g)

Wo $=$ the average weigth of the fish at the beginning of the study $\mathrm{T}_{1}(\mathrm{~g})$

$\mathrm{F} \quad=$ total of feed given during rearing period (g)

$\mathrm{D}=$ biomass of dead fish $(\mathrm{g})$

\section{Specific growth rate}

The specific growth rate of shrimp was determined using the following formula:

$$
\mathrm{SGR}=(\ln \mathrm{Wt}-\ln \mathrm{Wo}) / \mathrm{t} \times 100
$$

Note:

$\mathrm{SGR}=$ specific growth rate (\%/day)

$\mathrm{Wt}=$ the average weight of the fish at the end of the study (g)

Wo $=$ the average weigth of the fish at the initial of the study $\mathrm{T}_{1}(\mathrm{~g})$

$\mathrm{t}=$ rearing period

\section{Survival rate}

Shrimp survival rate was determined on a daily basis until the end of the research and was calculated using the following formula:

Note:

$$
\mathrm{SR}=\mathrm{Nt} / \mathrm{No} \times 100
$$

$\mathrm{SR}=$ survival $(\%)$

$\mathrm{Nt}=$ the number of the alive fish at the final observation (individuals)

No $=$ the number of the alive fish at the initial observation (individuals)

\section{Water quality}

Water quality parameter measurement of the rearing aquariums was performed at both the beginning (day 1) and the end (day 29) of the research. The parameters consisted of temperature 
$\left({ }^{\circ} \mathrm{C}\right)$, salinity ( $\left.\mathrm{g} / \mathrm{L}\right)$, dissolved oxygen (DO) $(\mathrm{mg} / \mathrm{L})$, TAN (mg/L), and $\mathrm{pH}$. The measurements were directly performed in the rearing aquariums and each parameter was measured using a specific measurement tool as follows: salinity AZ-8371 for salinity, PHEP Hanna instrument for $\mathrm{pH}$, dissolved oxygen meter Lutron DO-5509 for temperature and DO. The measurement results are presented in Table 1.

\section{Data analysis}

Data analysis were carried out using two methods i.e. ANOVA (SPSS 17) with an interval of confidence of $95 \%(\mathrm{P}<0.05)$ and descriptive analysis. ANOVA was used to analyze survival rate, total hemocyte count, phenoloxidase, phagocytic activity, respiratory burst, FCR, and SGR. An ANOVA test was followed by Duncan's post-hoc comparison test if differences were found (software SPSS statistic 22). Meanwhile, a descriptive analysis was used to analyze data such as phytochemical analysis results of ambon banana stem, WSSV confirmation with PCR, and clinical symptoms.

\section{RESULTS AND DISCUSSION}

\section{Results}

Survival rate post challenge test with WSSV showed that the lower the extract dose, the lower the survival rate of the test shrimp was (Figure 1). The supplementation of ambon banana stem extract at a dose of $0.5 \mathrm{~g} / \mathrm{kg} /$ day (treatment C) resulted in a survival rate $(100 \pm 0.00 \%)$ that was higher $(\mathrm{P}<0.05)$ than those of the positive control $(50 \pm 0.58 \%)$ and other treatments (A: $66.70 \pm 0.58 \%$ and B: $76.70 \pm 0.58 \%$ ). Mortality was observed on day 2 post challenge test in treatment $\mathrm{K}+$, while, it was only observed on day 3 and 4 post challenge test in ambon banana stem treatments at doses of 0.1 and $0.3 \mathrm{~g} / \mathrm{kg}$. The confirmation of WSSV presence was carried out by mean of PCR method. The results are presented in Figure 2.

Based on the observation results (in general) THC of the test shrimp in treatment C $(45.15 \pm 0.15$ $\times 10^{6} \mathrm{cell} / \mathrm{mL}$ ) was the highest during the 29 days research period compared to positive control $\left(3.83 \pm 0.35 \times 10^{6} \quad\right.$ cell $\left./ \mathrm{mL}\right)$, negative control $\left(28.65 \pm 0.15 \times 10^{6} \mathrm{cell} / \mathrm{mL}\right)$, A $\left(39.50 \pm 0.09 \times 10^{6}\right.$ cell $/ \mathrm{mL})$, and B $\left(42.25 \pm 0.23 \times 10^{6}\right.$ cell $\left./ \mathrm{mL}\right)$. The low ambon banana stem extract supplementation caused decreases in total hemocyte count in shrimp post challenge test (Figure 3).
Phenoloxidase observation results showed variations in phenoloxidase values between ambon banana stem extract treatments and control (Figure 4). Statistical test results revealed that treatment $\mathrm{C}$ had the highest phenoloxidase values both before $(0.59 \pm 0.03)$ and after $(1.03 \pm 0.08)$ challenge test compared to other treatments followed by treatment B and A.

Similar trends were observed between total hemocyte count and phenoloxidase activity observation results. Indeed, treatment $\mathrm{C}(0.5 \mathrm{~g} /$ $\mathrm{kg} /$ day $)$ had the highest respiratory burst $(\mathrm{P}<0.05)$ during the 29 observation days compared to other treatments. The supplementation of ambon banana stem extract at a dose of $0.5 \mathrm{~g} / \mathrm{kg} / \mathrm{day}(\mathrm{C})$, post challenge test, resulted in a respiratory burst activity $(0.95 \pm 0.04 \mathrm{OD})$ that was 2.8 times higher than that of control $(0.18 \pm 0.06 \mathrm{OD})$.

Phagocytic activity analysis results, presented in Figure 6, showed that treatment $\mathrm{C}$ had the highest phagocytic activity among treatments $(\mathrm{P}<0.05)$. The phagocytic activity value in ambon banana stem extract treatment at a dose of $0.5 \mathrm{~g} /$ $\mathrm{kg} /$ day (A) post challenge test $(49.67 \pm 3.06 \%)$ was about twice higher compared to control $(26.67 \pm 2.08 \%)$.

Clinical symptoms observation in the present research was carried out to view changes that occurred on the test shrimp due to WSSV infection and the clinical symptoms consisted of morphological changes and behaviors. Behavior changes involved parameters such as the shrimp swimming around aeration point, laziness, low responsiveness, low responsiveness to feed, and abnormal swimming behaviors. Morphological symptoms that were observed involved emptiness of the intestine and pale hepatopancreas.

The influence of supplementing ambon banana stem extract through the feed on both FCR and SGR is presented in Table 2. It was observed that the lower the ambon banana stem extract in the feed, the higher the FCR was, while the SGR was lower. Ambon banana stem extract supplementation at a dose of $0.5 \mathrm{~g} / \mathrm{kg} /$ day $(C)$ showed an FCR that was higher $(\mathrm{P}<0.05)$ compared to other treatments.

\section{Discussion}

The present research proved the presence of an immune system protection from the supplementation of ambon banana stem extract at a dose of $0.5 \mathrm{~g} / \mathrm{kg}$ feed with a daily supplementation frequency post-challenge test, which was supported by a high survival rate 
Table 1. Water quality parameters throughout the research

\begin{tabular}{lcc}
\hline Parameters & \multicolumn{2}{c}{ Treatments } \\
\cline { 2 - 3 } & Initial & Final \\
\hline Salinity $(\mathrm{g} / \mathrm{L})$ & 25 & $25-26$ \\
Temperature $\left({ }^{\circ} \mathrm{C}\right)$ & 28.6 & $28.3-28.4$ \\
DO $(\mathrm{mg} / \mathrm{L})$ & 5.9 & $7.1-7.3$ \\
$\mathrm{pH}$ & $7.2-7.3$ & $7.6-8.1$ \\
TAN $(\mathrm{mg} / \mathrm{L})$ & 0.30 & $0.02-0.23$ \\
\hline
\end{tabular}

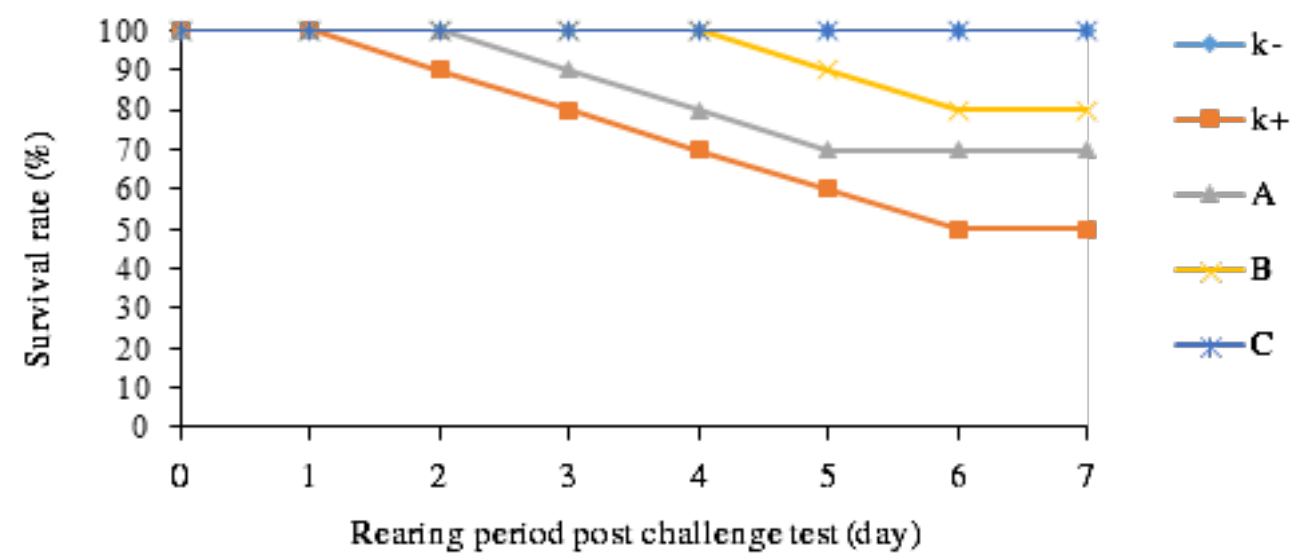

Figure 1. Survival rate of Pacific white shrimp post challenge test with WSSV. K- (without ambon banana stem extract supplementation and not infected by WSSV), K+ (without ambon banana stem extract supplementation but infected with WSSV), supplementation of feed containing Ambon banana stem extracts: A (0.1 g/kg/day), B (0.3 $\mathrm{g} / \mathrm{kg} /$ day $)$, and C (0.5 g/kg/day).

$(100 \pm 0.00 \%)$ compared to treatments without banana extract supplementation $(53.33 \pm 0.58 \%)$. The mentioned result was in line with the increment in immune response parameters such as total hemocyte count, phenoloxidase activity, respiratory burst, phagocytic activity, and WSSV confirmation results with PCR. This is believed to be a consequence of the role of active compound contained in ambon banana stem extract. Quantitative results of the phytochemical test on ambon banana stem extract revealed that it contained flavonoid (19.52\%), saponins (8.38\%), and tannins (4.94\%). A factor that influences a material in increasing the protective system of the shrimp body is an active compound contained in the extract that stimulates the defense system of the body. It inhibits or blocks the virus transcription and reduce its replication in host cells. It also increases the non-specific immunity and as an immunostimulant, the immunity of the host body (Sivasankar et al., 2015).

The high survival rate in treatment $\mathrm{C}$ is not only a consequence of the active compounds contained in ambon banana stem extract but also the dose of the extract that greatly influences the supplementation of the extract that functions as an immunostimulant. A low ambon banana stem extract dose in the feed led to a decrease in the immune response of the test shrimp. This was supported by the fact that doses of ambon banana stem extract, i.e. $0.1 \mathrm{~g} / \mathrm{kg} /$ day (treatment A) and $0.3 \mathrm{~g} / \mathrm{kg} /$ day (treatment $\mathrm{B}$ ), had fewer effects on test shrimp immune response. This was in line with Sajeevan et al. (2009) research, according to which, a high dose of immunostimulant can suppress the defense mechanism, while a low dose is not effective in triggering an immune response.

Shrimp only possess a non-specific immune system, meaning that it cannot produce antibody to fight against pathogens that enter the body. Thus, hemocyte plays the main role in cellular immune response that involves phagocytic process, melanization, encapsulation, cytotoxin, and communication between cells in fighting against the pathogen (Rowley \& powel, 2007). Post challenge test (day 1) observation results revealed a decrease in total hemocyte count in all treatments, indicating a migration of hemocyte cells from the body circulation system towards networks leading to a great number of infected viral cells (Yeh et al., 2009). Day 3, 5, and 7 post challenge test indicated the occurrence of 


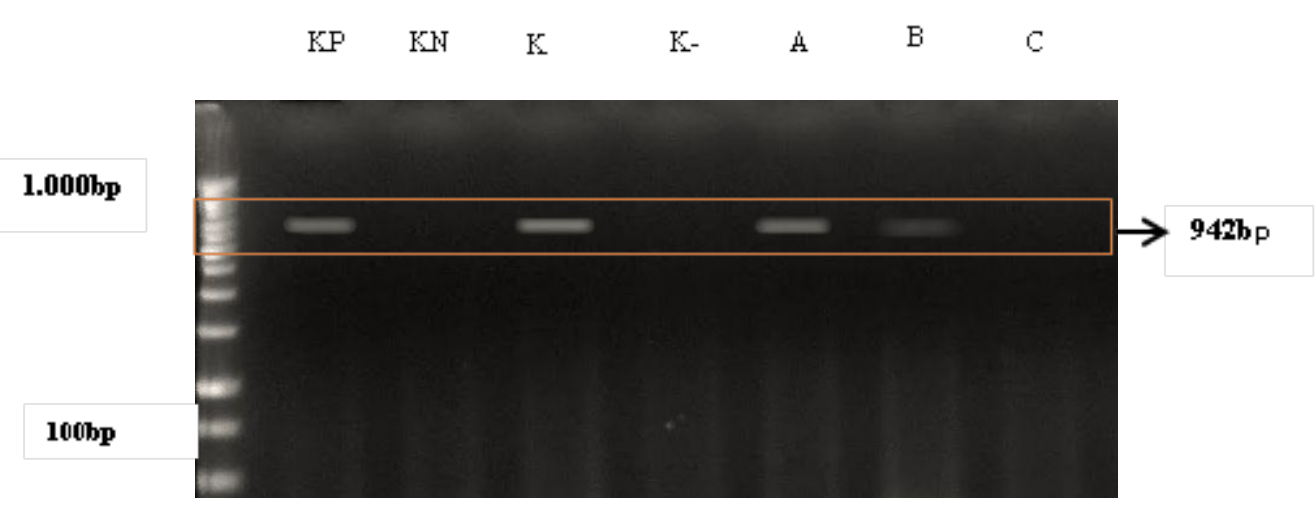

Figure 2. WSSV confirmation test of shrimp at the end of the rearing period. M (marker), KP ( WSSV infected shrimp DNA sample), KN (S), K+ (control +), K-(control-), A (0.1 g/kg per day), B (0.3 g/kg per day), and C (0.5 $\mathrm{g} / \mathrm{kg}$ per day).

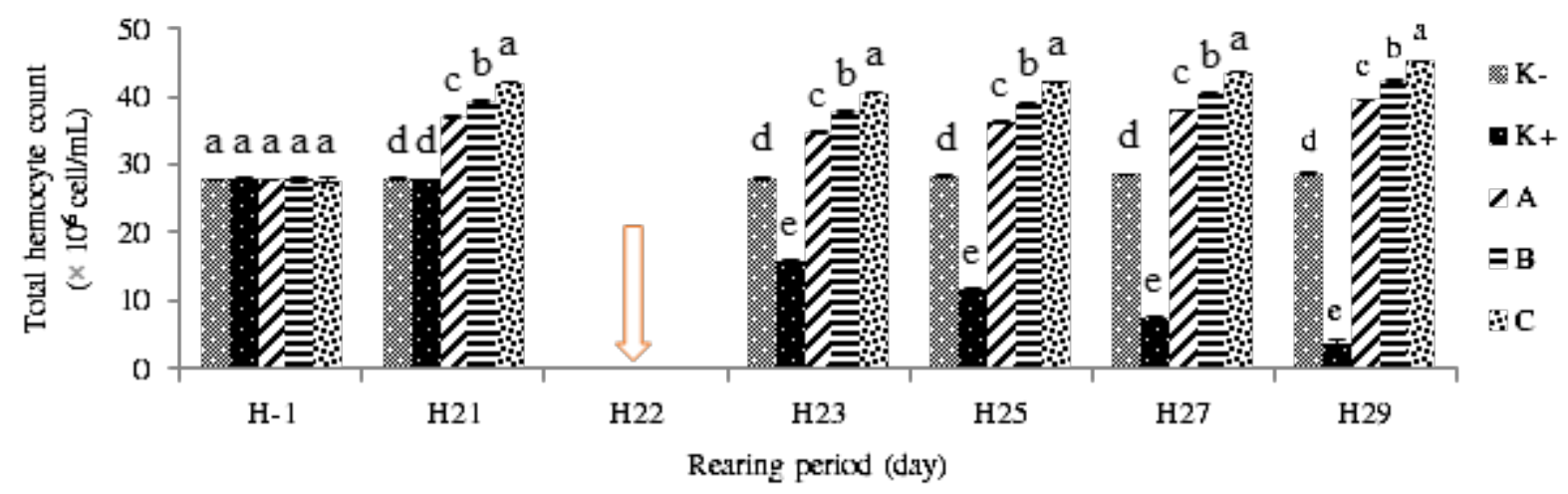

Figure 3. Total hemocyte count of Pacific white shrimp pre-treatment $(\mathrm{H}-1)$, pre-challenge test (H21), first day post challenge test $(\mathrm{H} 23)$, challenge test $(\mathrm{H} 22)$, day 3 post challenge test $(\mathrm{H} 25)$, day 5 post challenge test $(\mathrm{H} 27)$, and day 7 post challenge test (H29). Different letters above bars at the same observation period showed significant differences $(\mathrm{P}<0.05)$. K- (without ambon banana stem extract supplementation and not infected by WSSV), K+ (without ambon banana stem extract supplementation but infected with WSSV), supplementation of feed containing ambon banana stem extracts: A $(0.1 \mathrm{~g} / \mathrm{kg} /$ day $), \mathrm{B}(0.3 \mathrm{~g} / \mathrm{kg} /$ day $)$, and $\mathrm{C}(0.5 \mathrm{~g} / \mathrm{kg} /$ day $)$.

recovery processes expressed by increments in total hemocyte count in banana stem extract treatments. The highest total hemocyte count $\left(45.15 \times 10^{6}\right.$ cells $\left./ \mathrm{mL}\right)$ was observed in treatment C on day 29 (day 7 post challenge test) and was higher compared to $\mathrm{K}+\left(3.83 \times 10^{6} \mathrm{cell} / \mathrm{mL}\right)$. According to Ekasari et al. (2015), the high THC level is a consequence of a very high hemocyte mobilization in the shrimp body that led to an increase in both immunity and the recognition of foreign objects or pathogens that enter the body.

The activation of phenoloxidase system in shrimp involves the release of some molecules to carry out an immune response that functions in the foreign object introduction process, communication between cells, melanin formation, cytotoxic reactants production, encapsulation process, and the formation of nodules and capsules (Amparyup et al., 2013). The highest phenoloxidase activity was observed in treatment $\mathrm{C}(\mathrm{P}<0.05)$ post extract supplementation for 29 days. The increase in phenoloxidase activity will raise the ability of the shrimp to face foreign objects that enter such as the virus and perform phagocytosis. This shows that ambon banana stem extract supplementation played a role in the defense against the virus. The addition of natural materials can increase phenoloxidase activity and decrease the mortality level post infection. Lin et al. (2011) reported that immersion in Gracilaria tenuistipitata post challenge test had a higher phenoloxidase activity compared to control.

A result that was similar to those of total hemocyte count and phenoloxidase was the respiratory burst and the highest RB was observed in extract treatment at a dose of $0.5 \mathrm{~g} / \mathrm{kg} / \mathrm{day}$ $(\mathrm{P}<0.05)$. The respiratory burst is an immune response in Pacific white shrimp that can be observed during the removal of foreign objects through phagocytosis. The swallowing process of the foreign object by the phagosome involved the release of degradative enzymes that produce 
reactive oxygen intermediates (ROI) which are known as respiratory burst (RB) (Rodriguez \& Moullac, 2000). This proved that banana stem extract at a dose of $0.5 \mathrm{~g} / \mathrm{kg}$ in the feed can increase respiratory burst activity and the mentioned increment was in line with the increasing dose of the extract. Indeed, the supplementation of ambon banana stem extract through the feed at a high dose can raise the immune system of the body and the health status of Pacific white shrimp.

The observation of phagocytic activity revealed the occurrence of increments in treatment $\mathrm{C}$ infected with WSSV. The increment of phagocytic activity can indicate that the supplementation of ambon banana stem extract (in feed) as immunostimulant can stimulate or increase the immune system of the shrimp.
This was in accordance with Ridlo and Pramesti (2009) research, who stated that shrimp defence system parameters can also be determined by the phagocytic activity i.e. the ability of non-specific immune response cells to phagocytise pathogenic agents that enter the body, while treatment $\mathrm{K}+$ experienced a decrease in phagocytic activity, which was supported by the absence of immune system stimulation that functions in the phagocytic response.

Treatment $\mathrm{C}$ constitutes the treatment with the highest dose in accordance with the results from the immune parameters (total hemocyte count, phenoloxidase activity, respiratory burst, and phagocytic activity) during the 29 days of research. The results of the present research were proved by the results of the WSSV confirmation

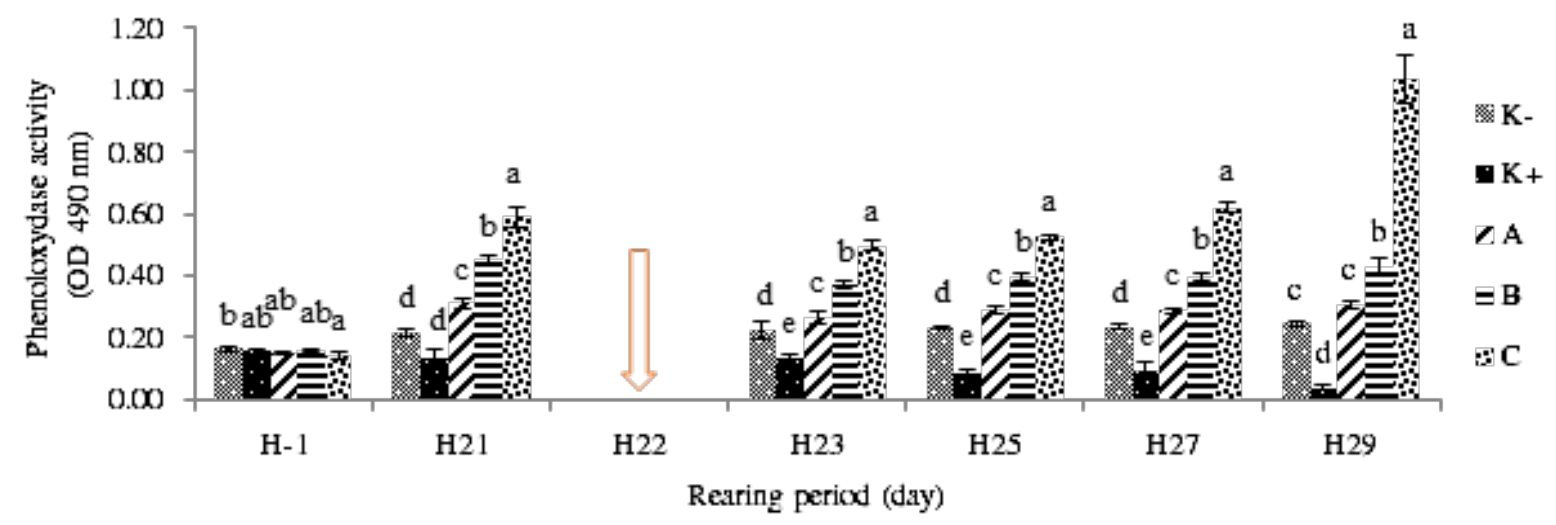

Figure 4. Phenoloxidase activity of Pacific white shrimp pre-treatment (H-1), pre-challenge test (H21), first day post challenge test $(\mathrm{H} 23)$, challenge test $(\mathrm{H} 22)$, day 3 post challenge test $(\mathrm{H} 25)$, day 5 post challenge test $(\mathrm{H} 27)$, and day 7 post challenge test (H29). Different letters above bars at the same observation period showed significant differences $(\mathrm{P}<0.05)$. K- (without ambon banana stem extract supplementation and not infected by WSSV), K+ (without ambon banana stem extract supplementation but infected with WSSV), supplementation of feed containing ambon banana stem extracts: A $(0.1 \mathrm{~g} / \mathrm{kg} /$ day $), \mathrm{B}(0.3 \mathrm{~g} / \mathrm{kg} /$ day $)$, and C (0.5 g/kg/day).

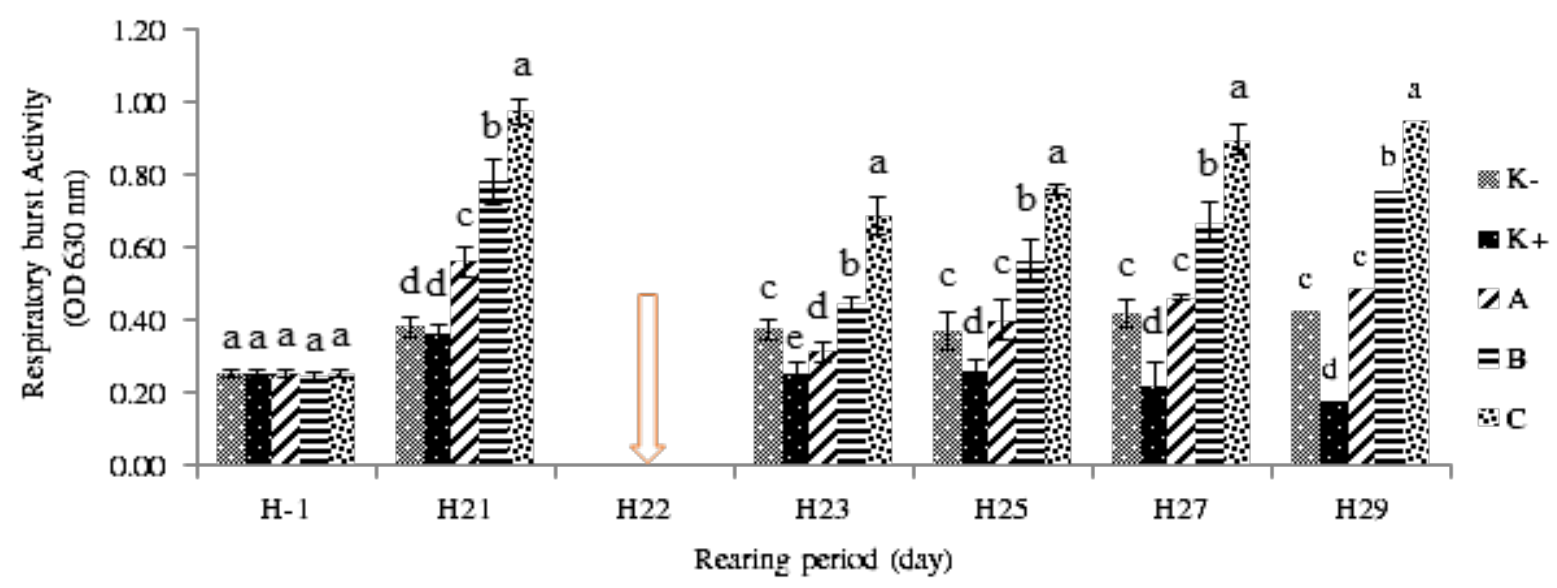

Figure 5. Respiratory burst activity of Pacific white shrimp pre-treatment (H-1), pre-challenge test (H21), first day post challenge test $(\mathrm{H} 23)$, challenge test $(\mathrm{H} 22)$, day 3 post challenge test $(\mathrm{H} 25)$, day 5 post challenge test (H27), and day 7 post challenge test (H29). Different letters above bars at the same observation period showed significant differences $(\mathrm{P}<0.05)$. K- (without ambon banana stem extract supplementation and not infected by WSSV), K+ (without ambon banana stem extract supplementation but infected with WSSV), supplementation of feed containing ambon banana stem extracts: A (0.1 g/kg/day), B (0.3 g/kg/day), and C (0.5 g/kg/day). 


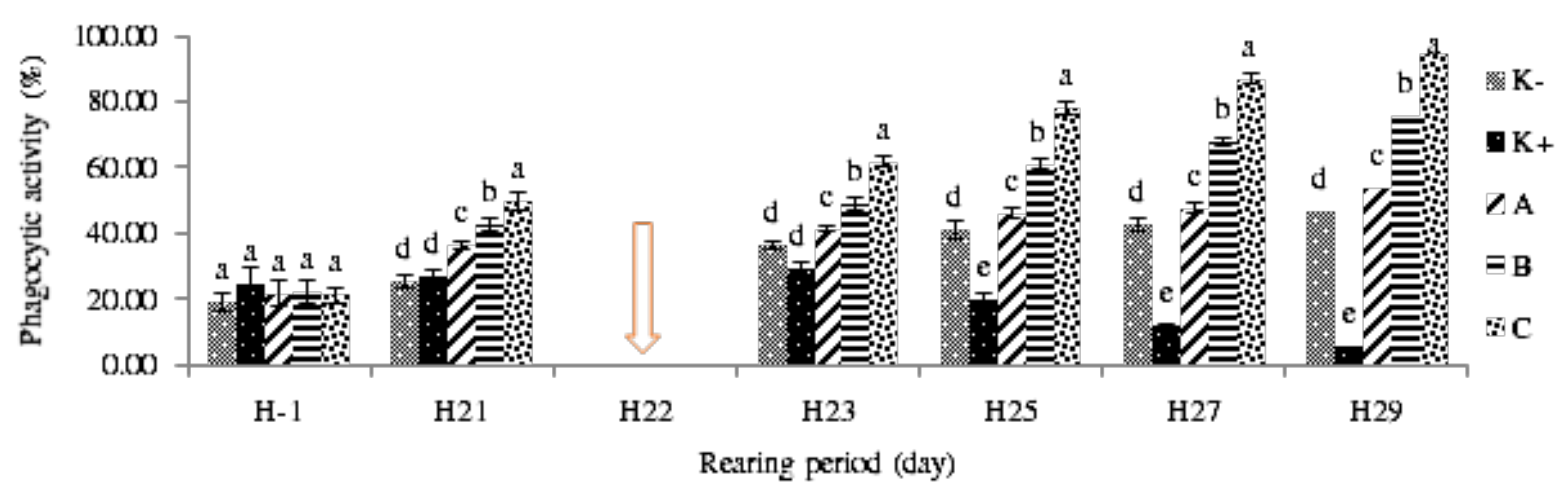

Figure 6. Phagocytic activity of Pacific white shrimp pre-treatment (H-1), pre-challenge test (H21), first day post challenge test (H23), challenge test (H22), day 3 post challenge test $(\mathrm{H} 25)$, day 5 post challenge test (H27), and day 7 post challenge test (H29). Different letters above bars at the same observation period showed significant differences $(\mathrm{P}<0.05)$. K- (without ambon banana stem extract supplementation and not infected by WSSV), K+ (without ambon banana stem extract supplementation but infected with WSSV), supplementation of feed containing ambon banana stem extracts: A $(0.1 \mathrm{~g} / \mathrm{kg} /$ day $), \mathrm{B}(0.3 \mathrm{~g} / \mathrm{kg} /$ day $)$, and C (0.5 g/kg/day).

Table 2. Water quality parameters throughout the research

\begin{tabular}{ccc}
\hline Treatments & Feed conversion ratio & Specific growth rate $(\% /$ day $)$ \\
\hline K- & $2.06 \pm 0.00 \mathrm{~d}$ & $3.90 \pm 0.07 \mathrm{~d}$ \\
K+ & $12.00 \pm 0.01 \mathrm{e}$ & $2.61 \pm 0.08 \mathrm{e}$ \\
A & $1.96 \pm 0.00 \mathrm{c}$ & $4.63 \pm 0.03 \mathrm{c}$ \\
B & $1.76 \pm 0.03 \mathrm{~b}$ & $5.20 \pm 0.15 \mathrm{~b}$ \\
C & $1.52 \pm 0.01 \mathrm{a}$ & $7.79 \pm 0.06 \mathrm{a}$ \\
\hline
\end{tabular}

Note: different letters in the same column showed significant differences $(\mathrm{P}<0.05)$

through PCR, while the confirmation results of WSSV with PCR observed in treatment $\mathrm{K}+$ i.e. positively infected by WSSV and these results were in line with the clinical symptoms that were observed from day 2 to day 7 post challenge test. The infected shrimp generally experience color changes (discoloration), the emptiness of the stomach, pale hepatopancreas, and lesions of Pacific white spots on the carapace (white spot) which are some criteria specific to WSSV infection.

The supplementation of ambon banana stem extract can not only increase the defense system of the shrimp against infection but also positively influence growth, as proved by parameters such as low feed conversion ratio (Table 2) in treatment $\mathrm{C}$ and an increment of the specific growth rate of the test shrimp. This was a consequence of the interaction between immunostimulant and growth. Lee and Gao (2012) explained that herbal effects influence dietary habit, digestive juice secretion, and feed consumption in general. The stimulation of digestive juice secretion, including saliva, digestive enzymes, bile, and mucus is considered as an important measure for feed additives.

\section{CONCLUSION}

The supplementation of ambon banana stem extract at a dose of $0.5 \mathrm{~g} / \mathrm{kg}$ and a daily feeding frequency over 29 days is able to increase the immune system, survival rate, and growth performance of Pacific white shrimp.

\section{REFERENCES}

Amparyup P, Charoensapsri W, Tassanakajon A. 2013. Phenoloxidase system and its role in shrimp immune responses against major pathogens. Fish and Shellfish Immunology 34: 990-1001.

Baratawidjaja KG, Rengganis I. 2010. Imunologi Dasar. Jakarta: Fakultas Kedokteran Universitas Indonesia.

[BPS] Badan Pusat Statistik. 2015. Produksi tanaman buah-buahan. http://www.BPS.go.id. [8 Oktober 2016].

Citarasu T. 2010. Herbal biomedicines: a new opportunity for aquaculture industry. Aquaculture International 18: 403-414.

Darvishpour H, Yahyavi M, Mohammadizadeh, 
Javadzadeh M. 2012. Effects of vitamin A, $\mathrm{C}, \mathrm{E}$ and their combination on growth and survival of litopenaeus vannamei. Advanced Studies in Biology 4: 245-253.

Ekasari J, Natipulu JLF, Surawidjaja EH. 2015. Immunity and growth of freshwater prawn fed with dietary $\beta$-glucan supplementation. Jurnal Akuakultur Indonesia 15: 41-48.

Hai NV. 2015. The use of medicinal plants as immunostimulants in aquaculture. Aquaculture 446: 88-96.

Hsieh S, Ruan Y, Li Y, Hsieh P, Hu C, Kuo C. 2008. Immune and physiological responses in Pacific white shrimp Penaeus vannamei to Vibrio alginolyticus. Aquaculture 275: 335341.

Huang YC, Yin ZX, Ai HS, Huang XD, Li SD, Weng SP, He JG. 2011. Characterization of WSSV resistance in selected families of Litopenaeus vannamei. Aquaculture 311: 5460.

Immanuel G, Imurugan MS, Marudhupandi T, Radhakrishnan S, Palavesam A. 2012. The effect of fucoidan from brown seaweed Sargassum wightii on WSSV resistance and immune activity in shrimp Penaeus monodon (Fab). Fish and Shellfish Immunology 32: 551-564.

Lakshmi B, Viswanath, Gopal DVRS. 2013. Probiotics as antiviral agents in shrimp aquaculture. Journal of Pathogens 2013: 1-13.

Lee JY, Gao Y. 2012. Review of the application of garlic, Allium sativum, in aquaculture. Journal of the World Aquaculture Society 43: 447-458.

Lin YC, Yeh ST, Li CC, Chen LL, Cheng AC, Chen JC. 2011. An immersion of Gracilaria tenuistipitata extract improves the immunity and survival of white shrimp Litopenaeus vannamei challenged with white spot syndrome virus. Fish and Shellfish Immunology 31: 1239-1246.

Loganayaki N, Rajendrakumaran D, Manian S. 2010. Antioxidant capacity and phenolic content of different solvent extracts from banana Musa paradisiaca and mustai Rivea hypocrateriformis. Food Science Biotechnology 19: 1251-1258.

Nunan LM, Lightner DV. 2011. Optimized PCR assay for detection of white spot syndrome virus (WSSV). Journal of Virological Methods 171: 318-321.

Pholdaeng K, Pongsamart S. 2010. Studies on the immunomodulatory effect of polysaccharide gel extracted from Durio zibethinus in Penaeus monodon shrimp against Vibrio harveyi and WSSV. Fish and Shellfish Immunology 28: 555-561.

Ridlo A, Pramesti R. 2009. Aplikasi ekstrak rumput laut sebagai agen imunostimulan sistem pertahanan nonspesifik pada udang Litopennaeus vannamei. Jurnal Ilmu Kelautan 14: 133-137.

Rodriguez J, Moullac GL. 2000. State of the art of immunological tools and health control of penaeid shrimp. Aquaculture 191: 109-119.

Rowley AF, Powell A. 2007. Invertebrate immune systems-specific, quasi-specific, or nonspecific? Journal of Immunology 179: 7209-7214.

Sajeevan TP, Philip R, Singh ISB. 2009. Dose/ frequency: a critical factor in the administration of glucan as immunostimulant to India white shrimp Fenneropenaeus indicus. Aquaculture 287: 248-252.

Simanjuntak AM. 2016. Application of banana stem extract as an immunostimulant for white spot disease control in white shrimp at floating cage [Thesis]. Bogor: Institut Pertanian Bogor.

Sivasankar P, Santhiya AV, Kanaga V. 2015. A review on plants and herbal extracts against viral diseases in aquaculture. Journal of Medicinal Plants Studies 3: 75-79.

SmithVJ, Brown JH, Hauton C. 2003. Immunostimulation in crustaceans: does it really protect against infection. Fish and Shellfish Immunology 15: 71-90.

Yeh SP, Chen YN, Hsieh SL, Cheng W, Liu CH. 2009. Immune response of white shrimp Litopenaeus vannamei after a concurrent infection with white spot syndrome virus and infectious hypodermal and hematopoietic necrosis virus. Fish and Shellfish Immunology 26: 582-588.

Yao D, Ruan L, Shi H. 2015. Identification of a c-Jun homolog from Litopenaeus vannamei as a downstream substrate of JNK in response to WSSV infection. Developmental and Comparative Immunology 49: 282-289. 